\title{
Letter from India: accent on accent and other English worries of a Ghati female
}

\author{
LAKSHMI PADMANABHAN
}

I AM A GHATI for several reasons ${ }^{1}$. First I live in Ghatkopar ${ }^{2}$. Been here for a quarter century. Secondly, Palghat ${ }^{3}$ in Kerala is where my ancestral house, called Kenath House is located. Thirdly, I like to call myself 'Daughter of the Western Ghats' in the grandiloquent manner of the late Benazir (May her soul rest in peace!) Besides, being Ghati is good, is on the way to being great. Mark my words. In the coming years you will see the rise and rise of the Ghatis. The fourth and, for the moment, final reason is, believe it or not, English, the language I teach was considered Ghati (Vernac, Vulgar and whatnot) by the elite in England once upon a time when Latin was the in thing in the cultured world.

Quite early in my life I bonded with English, for one should bond with the best. In turn, the best should bond with you, too. Which hasn't happened to my complete satisfaction. Fears, anxieties, complexes haunt me whenever I need to use the language which is nearly always, despite my being a resident Indian with a language of my own that I am free to make mistakes in without the fear of inviting ridicule. Accent, pronunciation, spelling, grammar, idioms, collocations - the English language is a whole minefield! Language is primarily speech, a matter of sounds. Hence the accent on accent and pronunciation. Accent in English is defined in one way by the individual segments and the emphasis on syllables. But it is much more than that in all languages, according to me. Accent comes by birth or exposure in early childhood to native speakers. With great effort people do acquire it with varying degrees of success. With all the effort I

LAKSHMI PADMANABHAN is a freelancer and Visiting Faculty, Post Graduate Centre, R. J. College, Ghatkopar W \& ICFAI's National College, Thane.Email: lexmipapan@gmail.com cannot speak Hindi like Amitabh Bachan ${ }^{4}$. Nor can he speak Malayalam like me. There, I beat the Shah-en-Shah 5 !!!

The Spoken English scene in India reflects the diversity for which we are so celebrated. Most Indians study in Indian schools and learn English as a second language. Their first language, the mother tongue influences the accent. (Other features of the mother tongue also affect their English). Even the English medium schools succeed only partly in teaching the 'Proper' English/British accent. I have read somewhere that the proper British speech cannot be taught. You need to be born with proper British lips, teeth and so on....The stiff upper lip, in other words!! Lesser breeds without the lip had better not try! The funny part is that each language group in India seems to believe that its accent/pronunciation is the correct Queenspeak and enjoys making fun of other Indian accents. A realistic and balanced approach to the accent issue is followed in the International Civil Aviation Organisation's test of English proficiency. I am indebted to a TOI report for this factoid. The Level 4 English test, as it is called, leaves ample room for accent variations. The influence of a pilot's first language or regional variation is allowed in his pronunciation, stress, rhythm and intonation so long as it does not interfere with meaning and comprehension.

Info of this kind is very reassuring to confused, unsure types like me. In my salad days as a cub college Miss I used to be insanely obsessed with doubts about my pronunciation and accent, had wondered whether what I spoke was English. I would even try it out on some Angrez ${ }^{6}$ whom I happened to meet at Chennai Central or some seminar on this or that at Hyderabad or wherever. My new doubt is whether I or for that matter my colleagues in India teaching English can be called 'English teachers'. Salman Rushdie, Arundhati Roy, 
Kiran Desai, her mother Desai and all earlier writers are now labelled Indian English writers. Going by that practice we are only Indian English teachers. My use of the word 'only' betrays my complexes. Is being named Indian English writer or teacher a demotion or a promotion? Is Indian English lesser English or better English? Will it ever gain as much status as American English which is the English now?

An emphatic 'Yes, it will' is the answer to my third question from David Crystal, Star Crystal Gazer into matters linguistic. Crystal, author of The Cambridge Encyclopaedia of the English Language has said recently that Indian characteristics of a new global 'Standard English' will signify the end of the primacy of American English. He is for real, by the way, as I have seen him in the flesh and heard him too at the British Council here in Mumbai a few years ago. Far from condemning our preference of the present continuous tense to the simple present he goes on to predict that the Indian's 'I am thinking, I am feeling and I am seeing' rather than 'I think, I feel, I see' could easily become sexy and part of global Standard English! Thank you very much Crystalji or Davidji or Bothji7. My! the womanhours I had spent on explaining the difference between the 'continuous' tense and her 'simple' cousin to my hapless students! My heart goes out to them with retrospective sympathy. I pray for similar pronouncements from linguists of Crystal's stature which could Indianise English further so that Ghatis like me can teach it with less difficulty.

To be specific I appeal to Crystal to relieve the Indian English teacher of the following. First in the list is the 'Articular Angst'. Terrible, those three small things - a, an \& the - their definiteness and indefiniteness, and the innumerable rules about their use and non use! All grammar books and classes mandatorily begin with these little goblins. The particles, dangling and otherwise are also goblins. There are bigger demons in the form of the perfect tense, the passive forms of all the tenses, the auxiliaries - the list is endless. All these boring basics, the bare bones or bricks, the correct English sentence (the Holy Grail for the vast majority of learners), the structure and architecture of the language should pass from the teacher to the student through some magical osmotic process.

The New Age has brought answers to some prayers. SMS and email are making mincemeat of the hallowed tradition of illogic in spelling which English has been burdened with ever since her snobbish dalliance with Latin in the distant past. Bernard Shaw's battle for logical spelling is being won on the handsets of Babes, Bhais $^{8}$, Bais ${ }^{9} \&$ Bhajiwallas $^{10}$. Short is sweet. All length abhorred. A, E, I, O, U will soon vanish from the written language. Reductio ad absurdum! (Latin, Latin).

Things $r$ moving 2 the other xtrm. What spelling will English teachers all over the world teach? Slusons 2 old wrris $r$ creating new probs. From the frying pan into the fire! From the old (f)rigidities to the new flux! Well, all the best, friends, learners and trainers - Indian and Global. God Bless U!!!

\section{Glosses and notes for words in this letter}

1 Ghati is a Marathi word originally meaning 'connected with mountains', implying someone from the back of beyond, considered unpolished, a country bumpkin etc.

2 Ghatkopar is a suburb in Mumbai.

3 Palghat is the name of a district in Kerala. Benazir's Bhutto's autobiography is titled 'Daughter of the East'.

4 Amitabh Bachan is a famous Bollywood actor, Super Star.

5 Shah-en-Shah is a title 'King of Kings'.

6 Angrez is the Hindi way of saying 'English'.

7 -ji is an honorific suffix.

8 Bhai: Hindi for brother, also used to refer to underworld dons

9 Bai: Marathi for woman, lady (old or young), also woman domestic help house maid

10 Bhajiwalla: seller of vegetables and herbs. 